\title{
The analysis of nutrient and fiber content of banana (Musa paradisiaca) sold in Pontianak, Indonesia
}

\author{
RIZKA HASANAH*, ENTIN DANINGSIH, TITIN \\ Biology Education Study Program, Faculty of Teacher Training and Education, Universitas Tanjungpura. Jl. Prof. Dr. H. Hadari Nawawi, Pontianak \\ 78124. West Kalimantan, Indonesia. Tel.: +62-561-740144. `email: sugarrizkah@gmail.com. \\ Manuscript received: 25 September 2016. Revision accepted: 2 February 2017.
}

\begin{abstract}
Hasanah R, Daningsih E, Titin. 2017. The analysis of nutrient and fiber content of banana (Musa paradisiaca) sold in Pontianak, Indonesia. Biofarmasi J Nat Prod Biochem 15: 21-25. This study aimed to determine the effect of varieties of bananas and marketplaces on the nutrients and fiber of bananas sold in Pontianak. Completely Randomized Design (CRD) Factorial model with main factors of varieties of banana (barangan, masak hijau, singapura), market places, namely traditional market, fruit stores, and side road kiosk, and the combination of varieties and market places of banana. The variable tests were carbohydrate, glucose, fructose, sucrose, protein, lipid, vitamin C, crude fiber, water, and ash content. The result was processed with SAS application 6.12 version using ANOVA CRD Factorial and significances followed by LSD $\alpha=0.05$. Results found that banana varieties significantly affected total carbohydrate, glucose, fructose, sucrose, vitamin C, lipid, and water but did not significantly affect crude fiber and ash. The marketplaces did not significantly affect total carbohydrate, glucose, fructose, sucrose, protein, vitamin C, crude fiber, and water but significantly affected ash content. The combination between varieties and marketplaces significantly affected specific nutrient content. Barangan was good on total carbohydrates, vitamin C, and ash, while masak hijau was highest on glucose, fructose, sucrose, and crude fiber. In addition, singapura was highest in protein, lipid, and water.
\end{abstract}

Keywords: Musa paradisiaca, nutrient content, Pontianak

\section{INTRODUCTION}

One of the local berries which are spreading a lot in Pontianak, West Kalimantan, is banana. Banana is easily obtainable and scattered in various places of sale fruit from traditional markets and fruit shops to the side road kiosk. Based on an observation, the species and varieties which were sold in Pontianak are barangan, masak hijau, kepok, ambon kuning, mas, raja, tanduk and nipah. As a local fruit sold at lower and reachable prices, bananas have various health benefits, such as helping to expedite our digestive system. Bananas also contain starch as the main source of energy-producing carbohydrates, vitamins, and minerals. A sweet taste fruit is also high in minerals such as potassium, magnesium, phosphorus, iron, and calcium. Bananas also contain vitamins, namely C, B complex, B6, and active serotonin as a neurotransmitter in the smooth functioning of the brain (Triyono 2010).

Local fruits such as bananas (personal communication) are distributed to various marketplaces in fresher conditions and require less time than imported fruits that need more time for distribution. Local bananas should be fresher and nutritionally better because they are taken directly from the harvesting place. It affects the freshness of the fruit and metabolic transportation processes that can affect the nutritional content of the fruit. However, nutritional information about bananas traded in Pontianak is still unknown. Bananas scatter in various places of sale fruit with different distribution conditions, which also cause the difference in the nutrient content of each fruit.
Traditional markets, fruit shops, and roadside kiosks have different circumstances. The traditional market and the side road kiosk have the more open condition than fruit stores. The traditional market and roadside kiosks' temperature is higher than in the fruit store. Another thing that also affects the nutrient content of the fruit is the storage area. A constant low temperatures (cold) storage can extend the physical quality (color and appearance/freshness, texture, and flavor) and nutritional value, especially vitamin $\mathrm{C}$ of imported fruit. A room temperature storage will lead to a quicker decrease in physical quality-organoleptic quality, and nutritional value, followed by the decay process (Tawali et al. 2004).

In fact, the consumption of fruits in Pontianak city is not as much as in other cities. BPS Pontianak (2014) data showed that fruit consumption was as much as $1.09 \%$ in Pontianak city in 2013. Lack of fruit consumption can be influenced by the level of the average income of the community (BPS Kalbar 2014). Based on the level of education, $27.44 \%$ of the people of Pontianak had elementary education, $4.90 \%$ of them had junior high school education, and $24.64 \%$ of them had senior high school education. In comparison, $11.69 \%$ of them had an SMK education, and $21.33 \%$ of these people had a university education. The profession level indicates the level of welfare. Rahardjo (2012) revealed that high education would be able to sustain a more feasible life. Although bananas can be purchased at affordable prices, climacteric they are perishable and easy to be rotten. The durability of the fruit is also a consideration for people to 
buy a banana. This study aimed to know the nutritional content of bananas sold in Pontianak City, West Kalimantan, Indonesia.

\section{MATERIALS AND METHODS}

\section{Materials}

The materials used in this study were 168 grams of various flesh of bananas (masak hijau, barangan, and Singapura) from various marketplaces in Pontianak City, West Kalimantan, Indonesia.

\section{Research method}

The research was conducted from March to April 2016 in the Laboratory of Biological Education, Faculty of Teacher Training and Education (FKIP) and Laboratory of Technology of Agriculture Product, Faculty of Agriculture, Tanjungpura University (Untan), Pontianak, Indonesia, using a completely randomized design (CRD) factorial. Three varieties and three marketplaces were used as main variables. Fruit observation was done by observing the morphology and anatomy of bananas which display the outer (physical) texture in the form of fruit rind; fruit skin color; freshness; and the shape of the fruit, while appearances observation was conducted with consideration of fruit ripeness including aroma (smell), taste and texture of the fruit flesh. The study began with preparing materials; preparing 168 grams of bananas meat which were used in the observation such as total carbohydrates observation by direct calculation (Plummer 1971), namely, by calculating the number of total carbohydrates by reduction of $100 \%$ grams of fat, protein, water, and ash. Benedict's quantitative test included glucose, fructose, and sucrose tests (Sudarmadji et al. 1997). The protein test was done using the spectrophotometric method. A fat test was done using soxhlet (SNI 2006a). The Vitamin C test was done using the iodine titration method; the level of Vitamin $\mathrm{C}$ was calculated by the total numbers of Iodine in ML 0:01 N) x (0.88 mg ascorbic acid) (Sudarmadji et al. 1997). The water content test was done using the gravimetric method (SNI 2006b). The crude fiber test used the gravimetric method (Sudarmadji et al. 1997). The Ash test used the done principle of direct incineration of ash content (Sudarmadji et al. 1997).

\section{Data analysis}

Data were analyzed using SAS version 6.12 applications in 1996 with RAL Factorial models using ANOVA. If the results showed a significant effect, it was continued using Least Square Different (LSD) at $\alpha=0.05$.

\section{RESULTS AND DISCUSSION}

\section{Result}

Masak hijau bananas were the sweetest when they were compared to barangan and singapura. It also has a little bit of softer banana flesh. Nonetheless, all fruit had good aromatic (Table 1). All of the fruits were unbruished.

Morphology and appearances of banana varieties sold in Pontianak were shown in Table 1, while nutrients and fiber contents were shown in Table 2 .

\section{Discussion}

\section{Physical characteristics}

The observation of characteristics of bananas (Table 1) consisted of observations of skin texture, color, freshness, shape, taste, aroma, and texture of the fruit flesh adjusted to the standard of consumable banana by Kerbel (2003). Masak Hijau has a softer flesh texture than those Barangan and Singapura. This statement refers to JafarizadehMalmiri et al. (2011) that banana fruit is climacteric and ripens rapidly after harvest. As reported by Marriott (1980), the ripening of banana is marked by the peel color change from green to yellow, the hydrolysis of starch to simple sugars, the softening of the pulp, and the development of aroma. It could also indicate a different maturity (Kerbel 2003).

Table 1. Morphology and appearances of banana varieties which were sold in Pontianak City, West Kalimantan, Indonesia

\begin{tabular}{|c|c|c|}
\hline Fruit varieties & Morphology & Appearances \\
\hline $\begin{array}{l}\text { Barangan } \\
\text { (Musa paradisiac var. barangan) }\end{array}$ & $\begin{array}{l}\text { The peel texture is smooth, with black spots at some parts; the peel } \\
\text { color is bright yellow, and fresh; the shape of the fruit is not bruised } \\
\text { and rotten. }\end{array}$ & $\begin{array}{l}\text { Sweet taste, aromatic, } \\
\text { soft. }\end{array}$ \\
\hline $\begin{array}{l}\text { Masak Hijau } \\
\text { (Musa paradisiaca } \text { var.sapientum) }\end{array}$ & $\begin{array}{l}\text { The peel's texture is smooth, does not have a scratch, there are } \\
\text { black spots at some parts, the peel is dark green, fruit does not } \\
\text { wither, with a proportional shape. }\end{array}$ & $\begin{array}{l}\text { Very sweet taste, } \\
\text { aromatic, and a little } \\
\text { bit softer. }\end{array}$ \\
\hline $\begin{array}{l}\text { Singapura } \\
\text { (Musa paradisiaca } \text { var.singapura) }\end{array}$ & $\begin{array}{l}\text { The peel's texture is smooth, the fruit peel is bright yellow, fruit } \\
\text { does not wither; fresh, solid, and in proportional shape. }\end{array}$ & $\begin{array}{l}\text { Sweet taste, aromatic, } \\
\text { soft. }\end{array}$ \\
\hline
\end{tabular}


Table 2. Results of ANOVA analysis of the nutrients and fiber per 100 grams of barangan, masak hijau and singapura which were sold in Pontianak City, West Kalimantan, Indonesia

\begin{tabular}{|c|c|c|c|c|c|c|c|c|c|c|}
\hline Variables & $\begin{array}{c}\text { Total } \\
\text { carbo- } \\
\text { hydrates }\end{array}$ & Glucose & Fructose & Sucrose & Fat & Protein & Water & $\begin{array}{l}\text { Crude } \\
\text { fiber }\end{array}$ & Vit. C & Ash \\
\hline Unit & g & mg & mg & mg & g & g & g & g & mg & g \\
\hline \multicolumn{11}{|l|}{ Varieties } \\
\hline Barangan & $26.68 \mathrm{a}^{* * *}$ & $4639.5 b^{* * *}$ & $4886.9 \mathrm{c}^{* * *}$ & $4546.7 b^{* * *}$ & $0.33^{\mathrm{ns}}$ & $0.96 b^{* * *}$ & $70.98 \mathrm{c}^{* * *}$ & $1.28^{\mathrm{ns}}$ & $8.71 \mathrm{a}^{* *}$ & $1.05^{\mathrm{ns}}$ \\
\hline Masak hijau & $23.6 \mathrm{~b}$ & $5219.7 \mathrm{a}$ & $5532.9 \mathrm{a}$ & $4801.9 \mathrm{~b}$ & 0.33 & $0.90 \mathrm{~b}$ & $74.39 \mathrm{~b}$ & 1.51 & $8.64 \mathrm{a}$ & 0.75 \\
\hline Singapura & $20.26 \mathrm{c}$ & $4899.9 \mathrm{~b}$ & $5194.0 \mathrm{~b}$ & $5115.3 \mathrm{a}$ & 0.34 & $1: 03 \mathrm{a}$ & $77.54 \mathrm{a}$ & 1.45 & $6: 26 b$ & 0.82 \\
\hline \multicolumn{11}{|l|}{ Market places } \\
\hline Traditional markets & $24.17^{\mathrm{ns}}$ & $4830.0^{\mathrm{ns}}$ & $5088.8^{\text {ns }}$ & $4733.4^{\mathrm{ns}}$ & $0: 33^{\text {ns }}$ & $0.96^{\mathrm{ns}}$ & $74.46^{\mathrm{ns}}$ & $1.61 \mathrm{a}^{* *}$ & $8.63^{\mathrm{ns}}$ & $0.85^{\mathrm{ns}}$ \\
\hline Fruit stores & 23.40 & 4988.9 & 5288.2 & 4889.1 & $0: 33$ & 0.96 & 73.63 & $1.27 \mathrm{~b}$ & 7.54 & 0.90 \\
\hline On the side road & 23.00 & 4940.3 & 5236.8 & 4841.5 & $0: 34$ & 0.96 & 74.83 & $1.36 \mathrm{ab}$ & 7.43 & 0.87 \\
\hline \multicolumn{11}{|l|}{ Combination } \\
\hline Barangan and traditional markets & $25.16^{\mathrm{ns}}$ & $\begin{array}{l}4513.35 \mathrm{bc} \\
*\end{array}$ & $\underset{* *}{4691.13 b}$ & $4423.08 \mathrm{bc} *$ & $0.35^{\mathrm{ns}}$ & $\begin{array}{l}1.08 \mathrm{a} \\
* *\end{array}$ & $72.27^{\mathrm{ns}}$ & $1.09 \mathrm{c} *$ & $9.97^{\mathrm{ns}}$ & $1.13^{\mathrm{ns}}$ \\
\hline Barangan and fruit shop & 27.87 & $4445.91 \mathrm{c}$ & $4712.66 \mathrm{~b}$ & $3182.91 \mathrm{c}$ & 0.30 & $0.93 \mathrm{~b}$ & 69.9 & $1.13 \mathrm{bc}$ & 8.53 & 1.03 \\
\hline Barangan and on the side road & 27.01 & $4959.35 \mathrm{ab}$ & $5256.91 \mathrm{a}$ & $4860.16 \mathrm{abc}$ & 0.35 & $0.85 \mathrm{~b}$ & 70.80 & $1.62 \mathrm{abc}$ & 7.63 & 0.98 \\
\hline $\begin{array}{l}\text { Masak hijau and traditional } \\
\text { markets }\end{array}$ & 24.22 & $5130.46 \mathrm{a}$ & $5438.28 \mathrm{a}$ & $5027.84 \mathrm{a}$ & 0.32 & $0.91 \mathrm{~b}$ & 73.98 & $2.03 \mathrm{a}$ & 8.31 & 0.58 \\
\hline Masak hijau and fruit stores & 23.83 & $5218.18 \mathrm{a}$ & $5531.27 \mathrm{a}$ & $5113.81 \mathrm{a}$ & 0.35 & $0.88 \mathrm{~b}$ & 74.09 & $1.35 \mathrm{bc}$ & 8.80 & 0.85 \\
\hline Masak hijau and on the side road & 22.84 & $5310.58 \mathrm{a}$ & $5629.21 \mathrm{a}$ & $5204.36 \mathrm{a}$ & 0.33 & $0.90 \mathrm{~b}$ & 75.10 & $1.15 \mathrm{bc}$ & 8.80 & 0.81 \\
\hline $\begin{array}{l}\text { Pisang singapura and traditional } \\
\text { markets }\end{array}$ & 20.82 & $\begin{array}{l}4846.12 \\
\text { abc }\end{array}$ & $5137.03 \mathrm{ab}$ & $4749.33 \mathrm{abc}$ & 0.35 & $0.90 \mathrm{~b}$ & 77.12 & $1.68 \mathrm{ab}$ & 7.63 & 0.83 \\
\hline Pisang singapura and fruit shop & 20.81 & $5302.47 \mathrm{a}$ & $5620.62 \mathrm{a}$ & $5196.42 \mathrm{a}$ & 0.33 & $1.08 \mathrm{a}$ & 76.94 & $1.36 \mathrm{bc}$ & 5.28 & 0.82 \\
\hline $\begin{array}{l}\text { Pisang singapoura and on the side } \\
\text { road }\end{array}$ & 19.15 & $4551 \quad \mathrm{bc}$ & $4824.33 \mathrm{~b}$ & $4460.00 \mathrm{bc}$ & 0.33 & $1.11 \mathrm{a}$ & 78.60 & $1.30 \mathrm{bc}$ & 5.87 & 0.82 \\
\hline
\end{tabular}

road

Note: $\mathrm{ns}=$ non significant $*=$ significant at $\alpha=0.05 * *=$ highly significant at $\alpha=0.01 * * *=$ very highly significant at $\alpha=0.001$. The letters on the back of the mean value which are not the same showed significant difference when tested by LSD $\alpha=0.05$.

\section{Total carbohydrate content in bananas}

There were differences in the total carbohydrate content of banana varieties, but there was no significant difference in the marketplaces and a combination of both (Table 2). The highest total carbohydrates are contained in barangan $(26.68 \mathrm{~g})$ and the lowest in singapura $(20.26 \mathrm{~g})$. Based on USDA (2016) standard, the standard of total carbohydrates in 100 grams of material is 22.84 grams. In combination, the highest total carbohydrate content was barangan sold in the fruit shop, and the lowest was singapura sold on the roadside kiosk. Still, statistically, it made no significant difference. The ripening level of bananas influences the nutritional content of bananas. Carbohydrates, glucose, fructose, and sucrose are directly proportional to the level of maturity of the fruit. Fitriningrum et al. (2013) stated that during fruit ripening, there are changes in various aspects, such as structure, texture, color, flavor, and biochemical processes. In the morphological observation of fruit (Table 1), masak hijau has a softer texture than the other bananas. It could indicate a faster ripening process than the other bananas. The age of bananas was unknown. Otherwise, the fruit's mature level and storage time affected the nutrient and fiber content. Fruit storage in a close and covered place can cause a decrease in $\mathrm{O}_{2}$ and an increase in $\mathrm{CO}_{2}$ and this situation can delay the time of ripening process. Delayed ripening process can reduce respiration and ethylene production. Storage of fruit in an open and uncovered place can increase $\mathrm{O}_{2}$ and decrease $\mathrm{CO}_{2}$ that will accelerate respiration product and increase ethylene production (Praeger et al. 2013).

\section{Glucose, fructose and sucrose contents in bananas}

There were differences in content of glucose, fructose and sucrose of bananas on fruit varieties and combinations, but there was no significant difference in bananas sold in the place of sales (Table 2). The highest glucose content was in masak hijau (5219.7 $\mathrm{mg}$ ) and lowest was in the barangan banana $(4639.5 \mathrm{mg})$. The highest glucose was masak hijau sold in the side road kiosk, and the lowest was barangan sold in the fruit shop. The highest fructose content was in masak hijau $(5532.9 \mathrm{mg})$ and the lowest was in the barangan (4886.9 mg. The highest sucrose content was singapura banana $(5115.3 \mathrm{mg})$ and the lowest was in barangan $(4546.7 \mathrm{mg})$. For the combination of varieties and those sold in market place, there were significant differences. The content of sucrose of masak hijau banana was highest regardless to the place of sale followed by singapura sold in fruit store. Levels of glucose, fructose and sucrose in fruit become higher when the fruit has ripened. Adao and Gloria (2005) said that fructose was 
formed at a faster rate which is consistent with the higher fructose levels accumulated in the ripened fruit. The fruit will be sweeter after the organic acid or starch is converted into sugar molecules that can reach a concentration of $20 \%$ in ripen fruit (Campbell et al. 1999). During the process of fruit ripening, via the enzymatic reaction, the starch will be broken down into simple sugars such as glucose, fructose and sucrose so that the fruit will become sweet (Fitriningrum et al. 2013). High sugar level of banana was characterized by observations when it was being sampled (Table 1), and was associated with post-harvest of fruit climacteric period. This is supported by Adeniji and Barimalaya's (2008) statement that after it is ripen, the skin turned from bright green to yellow because the chlorophyll of fruit was destroyed, and the color change occurred. The flesh became softer and sweeter due to the breakdown of sugar and the increase in its concentration.

\section{The fat content in bananas}

There are no differences in the fat content on banana varieties, bananas sold in market places and both combination (Table 2). Banana which has the highest fat content was singapura, namely, 0.34 grams which is not significantly different from masak hijau and barangan. For the market places, the highest fat content was on barangan sold in the side road kiosk, namely, 0.34 grams, followed by barangan sold in fruit shop and traditional markets which was 0.33 gram, According to USDA (2016), the three bananas have similar fat content with bananas in common.

\section{The protein content of bananas}

There were significant differences on the protein content of fruit varieties and on the combination of varieties and the ones sold in market places, but there was no significant difference on the market places. Singapura has a higher protein content $(1.03 \mathrm{~g})$ than masak hijau (0.96 g) and barangan $(0.90 \mathrm{~g})$. Climateric fruit such as bananas have high protein content when they are mature. Morphology on the skin colour has been observed (Table 1). According to Fabi et al. (2010), the increase of ethylene was characterized by discoloration of the fruit skin. Dominguez-Puigjaner et al. (1992) also states that the banana is climacteric fruits such as pears, apples, peaches, tomatoes and avocado which will have high levels of synthetic ethylene when they are mature. It is believed that ethylene regulates the expression of genes involved in the maturation, due to increased levels of protein in the banana pulp tissue which is in line with the maturity of the fruit. The high ethylene is indicated by the fragrant aroma of bananas.

\section{The water content of bananas}

There were significant differences of water content in the varieties of bananas but there was no difference in the market place and the combination (Table 2). The highest water content was 77.54 grams in Singapura and the lowest was in barangan (70.98 g). Siahaan et al. (2012) reported the water content was in line directly with the level of maturity of the fruit. The more mature the fruit, the higher the water content. the highest water content was in masak hijau, but the lowest water content was in Singapura bananas.

\section{Crude fiber content of bananas}

There were no significant differences of crude fiber content amongst the banana varieties, but there were highly significant difference in banana sold in the market place and significant difference in the combination of both (Table 2 ). The content of crude fiber is inversely proportional to the content of carbohydrates and sugar. Changes in crude fiber content during the maturation process occur because of polysaccharide degradation (Fitriningrum et al. 2013).

\section{The vitamin $C$ content of bananas}

There was a significant difference on the vitamin $\mathrm{C}$ content of the fruit varieties, but not on the fruit sold in the market place and the combination (Table 2). The highest vitamin $\mathrm{C}$ was in Barangan $(8.71 \mathrm{mg}$ ), which similar with that in masak hijau banana $(8.64 \mathrm{mg})$ however vitamin $\mathrm{C}$ content of singanpore was different significantly $(6.26 \mathrm{mg})$. The content of vitamin $\mathrm{C}$ in bananas decreases when ripe fruit was becoming ripen (Wall et al. 2006).

\section{The ash content of bananas}

There were no differences of ash content in the varieties, in bananas sold in market place, and the combination (Table 2). The ash content of fruit is inversely proportional to the level of maturity of the fruit. The more mature the fruit is, the lower the ash content is. Susanto (2009) stated that the higher the water content, organic matter content is getting higher; then ash content will be lower.

\section{General discussion}

Bananas are climacteric fruit influenced by the level of maturity, age, post-harvest, and the characteristics of the fruit in climacteric phases. According to Kader (1999) the maturity is the most important part in climacteric fruit. Maturity determines the length of life of the fruit until the post harvest period. Ripeness stage of fruits was characterized and classified by color, firmness and taste as unripe (physiological maturity stage), half-ripe and fullripe (consumption stage) (Hernandez et al. 2006). Based on the results of analysis, it is showed that there were significant difference of fruit varieties to the carbohydrate, glucose, fructose, and sucrose, vitamin $\mathrm{C}$, protein and water, but it did not affect the content of ash, crude fiber and fat. Overall for bananas sold in the market places, the nutrients in the fruit store was higher than in the traditional markets and side road kiosk. A test has been done to answer the question on the hypothesis, that there were significant differences on the content of crude fiber, but has no effect on carbohydrate, glucose, fructose, sucrose, vitamin $\mathrm{C}$, fat, protein, water and ash, due to market place of bananas, so that there was the influence of a combination of banana varieties with the sale of bananas in the city of Pontianak.

Differences in the contents of the fruit on the sale were affected by storage temperature and air temperature. 
According to Yulianti (2014) hot temperature can cause physical damage. According to the observation (Table 1), bananas were fresh. Therefore, the difference could come from other factor such as maturity at the time the bananas were sold. However, the sample age was not known. OECD (2010) said that good macronutrients such as potassium, nitrogen, phosphor, calcium, magnesium, and sulphur were needed in large amount for plant growth. Soil with lower $\mathrm{pH}$ and content of mangan and aluminium in it may be toxic and affect the plant growth, then it will decrease fruit quality. In addition, water in growing time causes fruit ripening.

Based on this research, we can choose a banana with the nutrients and fiber suited our needs respectively. Masak hijau were suitable to be processed for consumption or to be consumed directly, since they had high sugar content, and also fiber content that can help the digestive system. Banana fruit can be consumed as food reserves because they contain a high carbohydrate, and it also had high level of vitamin $\mathrm{C}$ and high content of ash which was better to be consumed directly without being processed first. Singapura has content of moisture, fat, and protein that can also be consumed directly without being processed.

We can buy Barangan, Masak Hijau and Singapura in three places, namely, traditional Market, fruit store and the road side kiosk because, generally, bananas in these three places did not have significant differences.

\section{ACKNOWLEDGEMENTS}

We would like to say thank you to the head of Technology of Product Agricultural Laboratory and the technician in it. This research was part of fruit research funded by DIPA FKIP Tanjungpura University and independently.

\section{REFERENCES}

Adao RC, Gloria MBA. 2005. Bioactive amines and carbohydrate changes during ripening of 'Prata' banana (Musa acuminate $x \mathrm{M}$. balbisiana). Food Chem 90: 705-711. DOI : 10.1016/j.foodchem.2004.05.020.

Adeniji TA, Barimalaya IS. 2008. Genotypic variation in fruit ripening timer and weight reduction among a selection of new Musa hybrids. J Appl Sci Environ Manag 12. 27-32.

BPS Kalbar. 2014. Kalimantan Barat dalam Angka. (unduh). (http.bpskalbar.go.id, 15 Oktorber 2015). [Indonesian]

BPS Kota Pontianak. 2014. Kota Pontianak Dalam Angka. BPS Kota Pontianak, Pontianak. [Indonesian]

Campbell NA, Reece JB, Mitchel LG. 1999. Biology. Fifth Edition. Addison Wesley Longman, USA.

Dominguez-Puigjaner E, Vendrell M, Ludevid MD. 1992. Differential protein accumulation in banana fruit during ripening. J Plant Physiology 98:157-162.

Fabi JP, Peroni FHG. Gomez MLPA. 2010. Papaya, Mango and Guava Fruit Metabolism during Ripening : Postharvest Changes ffecting
Tropical Fruit Butritional Content and Quality. Global Science Book, New York.

Fitriningrum R, Sugiyarto, Susilowati A. 2013. Analisis kandungan karbohidrat pada berbagai tingkat kematangan buah karika (Carica pubescens) di Kejajar dan Sembungan, Dataran Tinggi Dieng, Jawa Tengah. Bioteknologi 10: 6-14. [Indonesian]

Hernandez Y, Lobo MG, Gonzalez M. 2006. Determination of vitamin C in tropical fruits: A comparative evaluation of methods. J Food Chem 96: 654-664.

Jafarizadeh-Malmiri H, Osman A, Tan CP, Abdul Rahman, R. 2011. Evaluation of effectiveness of three cellulose derivative-based edible coatings on changes of physico-chemical characteristics of 'Berangan' banana (Musa sapientum cv. Berangan) during storage at ambient conditions. Intl Food Res J 18(4): 1381-1386.

Kader AA. 1999. Fruit Maturity, Ripening, and Quality Relationships. Deparment of Pomology. University of California. Proc Int. Symp. on Effect of Pre- and Post Harverst Factors on Storage of Fruit. Acta Hort ISHS 485: 203-208.

Kerbel E. 2003. Bananas and Plantain. Dole Fresh Fruit International Ltd, San Joe, Costa Rica.

Marriott J. 1980. Bananas-physiology and biochemisty of storage and ripening for optimum quqlity. Crit Rev Food Sci Nutr 13: 41-88.

OECD. 2010. The Biology of Musa L. (Banana), Ver. 1. Office of the Gene Technology Regulator, Australian Government Department of Health and Ageing, Canberra.

Plummer DT. 1971. An Introduction to practical Biochemistry. McGrawHill, London.

Praeger U. Linke M, Jedermann R, Moehrke A, Geyer M. 2013. Effect Of Storage Climate On Green-Life Duration of Bananas. Germany. http://studylib.net/doc/18566451/effect-of-storage-climate-on-green

Rahardjo M. 2012. Model Pembelajaran Inovatif. Gava Media, Jogjakarta. [Indonesian]

Siahaan KJ, Julianti E, Ridwansyah. 2012. Aplikasi perangsang pematangan pada buah pisang barangan (Musa paradisiacal L) yang dikemas dengan kemasan atmosfir termodifikasi. J. Rekayasa Pangan dan Pertanian 1 (1): 57-69. [Indonesian]

SNI. 2006a. SNI 01-2354.3-2006. Cara uji kimia-Bagian 3: Penentuan kadar lemak total pada produk perikanan. [Indonesian]

SNI. 2006b. SNI-01-2354.2-2006. Cara uji kimia-Bagian 2: Penentuan kadar air pada produk perikanan. [Indonesian]

Sudarmadji S, Haryono B, Suhardi. 1997. Prosedur Analisa untuk Bahan Makanan dan Pertanian. Liberty, Yogyakarta. [Indonesian]

Susanto A. 2009. Uji korelasi kadar air kadar abu water activity dan bahan organik pada jagung di tingkat petani, pedagang pengumpul dan pedagang besar. Seminar Nasional Teknologi Peternakan dan Veteriner 2009. [Indonesian]

Swastawati F, Surti T, Agustini TW, Riyadi PH. 2013. Karakteristik kualitas ikan asap yang diproses menggunakan metode dan jenis ikan berbeda. Jurnal Aplikasi Teknologi Pangan 2 (3): 126-132. [Indonesian]

Tawali AB. 2004. Pengaruh suhu penyimpanan terhadap mutu buah buahan impor yang dipasarkan di Sulawesi Selatan. Volume 2. Universitas Hasanuddin, Makassar. [Indonesian]

Triyono A. 2010. Pengaruh Maltodesktrin dan Substitusi Tepung Pisang (Musa paradisiaca) Terhadap karakterisitik Flakes. Balai Besar Pengembangan Teknologi Tepat Guna- LIPI. Prosiding Seminar Nasional Teknik Kimia "Kejuangan". Pengembangan Teknologi Kimia untuk Pengolahan Sumber Daya Alam Indonesia. [Indonesian]

USDA. 2016. Nutrient Values And Weight For Banana Raw For Edible Portion. United States Department of Agriculture, Washington DC www.ndb.nal.usda.gov.

Wall MM. 2006. Ascorbic acid, vitamin C, and mineral composition of banana (Musa sp.) and papaya (Carica papaya) cultivars grown in Hawaaii. J Food Composit Anal 19: 434-445.

Yulianti, Y. 2014. Penanganan Sortasi Buah Apel Fuji Sun Moon (Malus sylvestri L) di Hypermart Gorontalo Kota Gorontalo. [Skripsi]. Universitas Negeri Gorontalo, Gorontalo. [Indonesian] 